\title{
Village Health Workers: Considering Their Potential Role in the Current Ebola Virus Disease (EVD) Outbreak
}

\section{Abstract}

An overview of the Ebola virus disease (EVD) in the current outbreak was discussed. The void created by the loss of health care workers and the increased need for village health workers (VHWs) was highlighted. The clinical manifestations of EVD in past and current outbreaks were also examined. The implementation of VHWs in various countries before the 1978 Declaration of Alma, Ata was reviewed. Village health workers are also called community health workers (CHW). They are called by different names around the world and they have different levels of training. Some are trained in only one area like the traditional birth attendants. The village health care worker was identified as part of Primary Health Care and their roles in different countries were explored. The positive impact in the health status of the communities after the introduction of VHW was also highlighted. In this present outbreak, there has been antagonism towards health care workers which has sometimes ended fatally. As part of community participation, VHWs are selected by the community they serve and this would reduce the antagonism sometimes directed at health care workers that are viewed as strangers and not as members of the community. The potential role of VHW as contact tracers, counselors, health educators, temperature monitors and first contact with the health system in the control of EVD was also highlighted. The governments of the three most affected countries should collaborate with countries that have employed the use of VHWs in EVD outbreaks.
Titilola T. Obilade MBBS, Ph.D.

\section{Contact information:}

Titilola T. Obilade MBBS, MPH, FMCPH, MWACP, MILD, Ph.D.

Senior Education Specialist Learning Sciences and Technology 144J Smyth Hall.

Virginia Polytechnic Institute and State University.

Blacksburg, Virginia, 24061- 0488.

”obilade@vt.edu

\section{Keywords}

Ebola Virus Disease (EVD); Village health workers (VHW), community health worker (CHW), Primary Health Care, Alma Ata Declaration, health care workers; community participation; filoviral outbreak 


\section{Introduction}

The current Ebola virus disease (EVD) outbreak started more than a year ago with the index case identified as a two year old child from the Republic of Guinea [1, 2]. The source of infection of the index case has not been found. A recent study suggested a probable contact with bats while the child was playing in a hollow tree housing the bats [3].The Ebola virus is one of the causative pathogen of the viral hemorrhagic fevers [4]. Viral hemorrhagic fevers are caused by 23 enveloped RNA viruses from four distinct taxonomic families of viruses: Filoviridae, Arenaviridae, Bunyaviridae and flaviviridae [4]. The Filoviridae family is home to three virus genera: Marburgvirus (MARV), Ebolavirus (EBOV) and Cuevavirus $[4,5]$.

Five species of Ebolavirus have been isolated from the Ebolavirus genus. These species are Sudan ebolavirus (SEBOV/SUDV), Zaire ebolavirus (ZEBOV/EBOV), Côte d'Ivoire ebolavirus (CIEBOV/TAFV), Bundibugyo ebolavirus, (BEBOV/BDBV) and the Reston ebolavirus (REBOV/RESTV) [4]. Four of the five species of Ebola virus cause symptomatic infection in humans except the Reston ebolavirus [4, 6]. Marburgvirus and Cuevavirus each have a single species in their genera: MARV species and LLOV species [5, 7]. Marburgvirus is pathogenic to humans. The first recorded filoviral hemorrhagic fever was from the Marburg virus [8]. Cuevavirus was recently discovered inside some caves in Spain that were harboring dead bats [5]. Human infection has not been reported in Cuevavirus. The fruit bat is probably the reservoir for the Zaire ebolavirus but it has never been conclusively isolated from the animal $[9,10]$. When fruit bats and several other vertebrate animals were inoculated with the ebolavirus, the results were inconclusive [10].

\section{The Zaire Ebola Virus Species}

The Zaire Ebola virus species is responsible for the current outbreak that has been devastating the countries of Guinea, Sierra Leone and Liberia [11]. Briefly, EVD was in Nigeria, Senegal and Mali [12-14] but the disease was curtailed in these three countries through aggressive isolation, contact tracing, close monitoring and aggressive supportive care. Most of the infected nationals from foreign organisations infected with the virus while working in Africa were successfully treated in special units abroad.

The Ebola virus requires the highest level of biosafety containment because of the infectivity, the severity of disease, the transmissibility and the risk of infection through aerolization [5, 15-18]. Nonhuman primates, bats, rodents, humans, mosqui-

Figure 1: Illustration of taxonomic family, genera and species of Ebola virus.

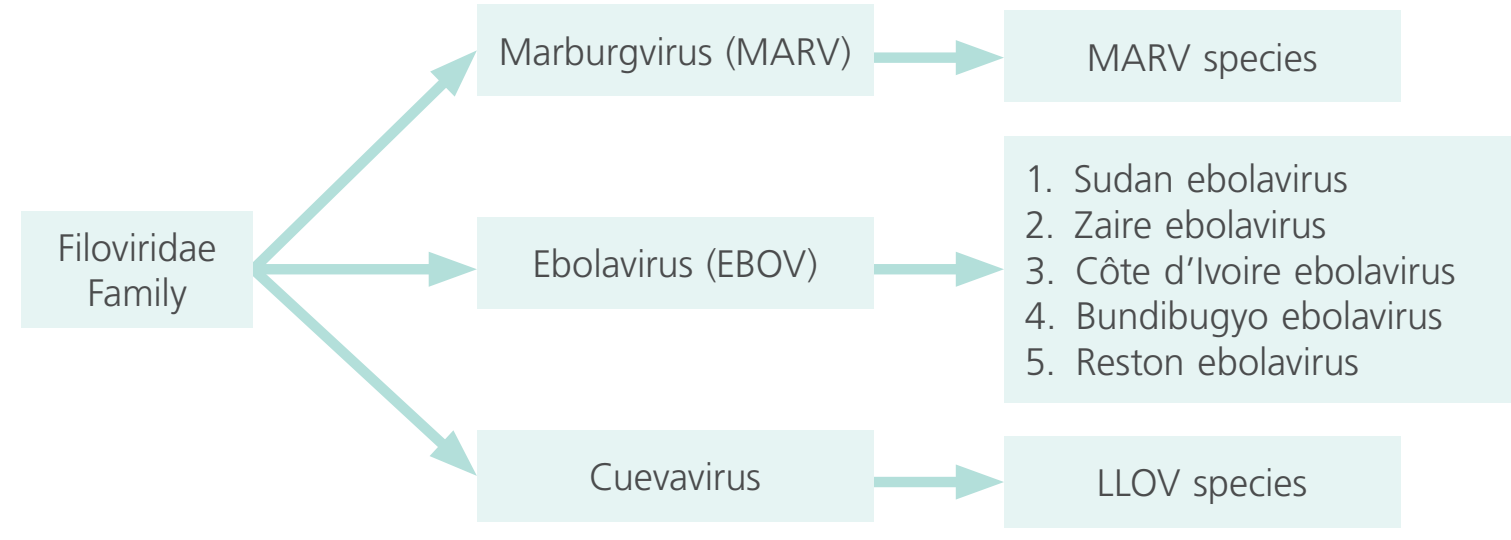


toes and ticks can transmit the disease [4, 19]. Infection is usually by contact with body fluids of infected humans or animals. From Guinea, the disease was able to spread to neighboring Sierra Leone and Liberia through infected persons and through weak infection control systems. The burial cultural practice of the people in the affected nations was another factor that facilitated the spread of the disease. Previous outbreaks in other African countries were far from developed road networks but the human movements around the bordering towns of the index case facilitated the spread. Initial signs and symptoms can mimic diseases that are endemic in the region [4]. Malaria, typhoid fever, and Lassa fever are endemic in the affected regions. The incubation period is 4 to 21 days [4]. Since 1976 when the virus was first identified from simultaneous infections in south Sudan and Zaire (now Democratic Republic of Congo) $[20,21]$ a licensed cure or treatment still does not exist. Therefore, treatment is mainly supportive but prevention of EVD is achievable through intensive infection control.

\section{Clinical Manifestations of EVD}

Ebola virus disease was formerly called Ebola hemorrhagic fever but the name was changed because it is not all cases of the Ebola virus infection that gives rise to hemorrhage [11]. Although visible hemorrhage does not occur in all infected cases, a distinctive feature in infected cases is the pathology of the vascular system leading to increased vascular permeability [22]. A review of literature on persons infected with the filoviral hemorrhagic fevers showed that they usually have fevers, rash and thrombocytopenia [23]. They become abruptly ill with non-specific symptoms that include fever, fatigue, headache, myalgia, nausea, vomiting and diarrhea [23].

Physical examination: The body temperature ranges between $39^{\circ} \mathrm{C}$ to $40^{\circ} \mathrm{C}$. The body temperature can also swing to below normal [23]. Hypo- tension is a common feature in fatally infected patients and death usually occurs from hypovolemic shock [23]. Tachypnea has been observed in fatally infected patients $[24,25]$. A maculo popular rash usually occurs during the early stage of the disease; usually focal but later becomes confluent [23].

The epidemiologic study of infected patients in Democratic Republic of the Congo in a 1995 outbreak showed that some of the patients that developed fever, asthenia, oral mucosal redness, dysphagia and conjunctivitis survived but fatally infected patients usually had hiccups, dyspnea, hemorrhagic manifestations, neuropsychiatric abnormalities and oligoanuria in addition to some of the other clinical signs and symptoms observed in those that survived [25]. Recovery from the disease is prolonged with hair loss, uveitis, asthenia, weight loss, anemia and sometimes loss of vision $[25,26]$. Epidemiologic studies in the current outbreak have shown that case fatality was lower in those less than 21 years of age but higher in those older than 45 years old [27]. Laboratory findings also showed that fatally infected patients had elevated blood urea nitrogen, aspartate aminotransferase and creatinine [27]. In addition, patients with a higher EBOV viral load had a poorer prognosis [27]. Out of 44 known outcomes in the epidemiologic study, only one patient had hemorrhagic manifestation while in hospital [27].

\section{Death and Dearth of Health Care Workers}

The West African countries most affected by the EVD are among the lowest ranked in the United Nations Development Index (UNDP) Human Development Index [28]. The UNDP Human Development Index is a comparative measure of life expectancy, literacy, education and standard of living in all the countries of the world. The countries most affected do not have the foundational structure to meet the demands of the care needed to fight the devastations caused by EVD. Further, they lack the human resources to tackle the disease. 
Before the onset of the disease, doctors in these regions were not enough. In the most affected countries, before the crisis, there was a ratio of one to two doctors to 100,000 people [29]. However, about a year since the EVD outbreak, more than 600 health care providers have been infected and more than half of them have died including medical doctors [30] reducing the number of available doctors even further. At the January 2015 report of the World Health Organisation (WHO) report, the WHO Director General reported that 850 health workers had been infected and 500 of them had died [31]. It is not all the health care providers that were infected that were directly involved in the care of EVD infected patients. Some were infected in the laboratories and some got infected through casual body contact with an undiagnosed person [30]. Apart from doctors and nurses, midwives, cleaners, ambulance drivers, pharmacists, community health workers have been infected and died from EVD [32]. In Guinea, retired doctors were recalled to help manage the surge of infected patients [30]. Some health care workers including journalists were murdered by the community because of misplaced beliefs on the cause of EVD [33, 34].

\section{Concept of Village Health Workers before the 1978 Alma Ata Declaration}

Through human history, communities have taken responsive, collective action about their health. One of the most popular concepts of the village health worker (VHW) dates back to the Chinese barefoot doctors, the former Soviet's rural feldsher and to Thailand's village health volunteers $[35,36]$. Other national concepts of the village health worker also existed in Cuba and in Tanzania [37] before the formal adoption of Primary Health Care in 1978 [38]. Iran, Niger and Venezuela had village health workers as extensions of their health systems. Guatemala, India and Indonesia developed local community programs to provide, simple and inexpensive basic health care [37].
In 1961, Tanzania had village medical helpers, rural medical aides, health auxiliaries and rural medical aides and maternal and child health aides that were posted to rural areas to deliver basic health services to the rural populations [39]. By 1974, Niger had 780 village health workers in 362 villages and 467 midwives in 179 villages [40].

In 1963, the rural health and extension services of Niger trained village workers to provide health care to villages that were far from the dispensary. The village health workers were trained and given dispensary kits that consisted of items that could be used to treat malaria and first aid kit for minor cuts and bruises. A quote from Niger's Ministry of Health's Quadrennial plans 1965-1968, 1971-1974 and the ten year prospectus 1965-1975;

The training of a village health worker will enable him to carry out the routine cleaning and dressing of wounds and to administer simple medicaments, and will facilitate hygiene measures and the cooperation of the population in mass health service campaigns. This training will be given in close cooperation with the rural extension services and will lead to the local community assuming responsibility for public health. As a rule, these village health workers will be volunteers. The village community will make itself responsible for renewal of the standard village pharmacy kit. The village health worker will be appointed by the village and will have to bear a certain responsibility ...General awareness (as regards suitable health attitudes and habits) will be ensured by a constant informational and educational effort carried on by a village team (village health workers, traditional birth attendants) acting as permanent representatives of the health service...

Fournier G \& Djermakoye IA. Village Health Teams in Niger (Maradi Department). In (WHO) Health by the people. 1975.pp.131 
In the 1950s, China did not have enough trained medical doctors for a population of $540 \mathrm{mi}-$ llion at the time. Trained doctors were concentrated in the urban areas and the rural populations were left without trained doctors. In efforts to overcome the problem posed with scarcity of doctors especially in the rural areas, members of the community were trained in skills like vaccinations and in first aid. Members of the community that were trained were known as the barefoot doctor [35].

The Chinese term, chijiao yisheng is literally translated into English as barefoot doctor. However, the Chinese contextual meaning of chijiao is in reference to the south peasants that work without shoes in the rice paddies [35]. The barefoot doctors wear shoes. The Chinese yisheng refers to a peasant doctor and not one that has gone through a medical school. It is not a derogatory term. At the time, the barefoot doctors were usually peasants that would work in the farms during the farming seasons and at other times would give preventive services to members of the community.

Apart from the barefoot doctors, the worker doctor and Red Guard doctor were also used in ways similar to the barefoot doctor. The worker doctor was someone working in the factory that was trained to give first aid to the other workers. The Red Guard doctor was usually a female that worked in the health centers in the cities as a physician's assistant [35].

\section{The 1978 Declaration of Alma Ata}

In September 1978, representatives of WHO and the United Nations Children's Fund (UNICEF) met in Alma Ata, USSR (now Almaty, Kazakhstan), to address the disparities in health [38]. At the Alma Ata meeting, Primary Health Care was identified as the key to attain health for all by the year 2000.
Primary health care is essential health care based on practical, scientifically sound and socially acceptable methods and technology made universally accessible to individuals and families in the community through their full participation and at a cost that the community and country can afford to maintain at every stage of their development in the spirit of self-reliance and selfdetermination.

Declaration of Alma-Ata, International Conference on Primary Health Care, Alma-Ata, USSR, 6-12 September 1978

Village health workers are the first level of contact that the community has contact with especially in places where the geographic and economic access to a medical doctor may be challenging. In many developing nations of the world, shortages of doctors and other skilled health workers lead to increase morbidity and mortality from diseases that are preventable and curable.

They are called by different names around the world. They have different functions and different levels of training. In Africa, they have been trained in the delivery of babies, caesarian surgery, home visits, in health education and in weight monitoring [41]. They have played major roles in maternal and child health encouraging women to register for antenatal care and detect danger signs. They have encouraged women to go for breast cancer screening.

They are also known as community health workers (CHWs), Lay Health Workers (LHWs), volunteer health workers, community health promoters, and natural helpers. They are known by various names in many countries. In Pakistan, they are called lady health workers [42]. They also have specialized roles and are called traditional birth attendants and HIV/ AIDS communicators.

The rest of this paper would examine the role of village health workers in different countries and the outcome of their impact. After examining their role, it would propose a potential role for VHWs in the 
current EVD outbreak. In the 21st Century, the global community has never experienced a prolonged rapidly killing infectious disease outbreak of such exponential proportions. The control of EVD must involve aggressive contact tracing and close monitoring of contacts, isolation of infected persons, effective infection control and intensive supportive care. One of the hallmarks of control is quick identification of cases. The heavy loss of health care workers either through infection or through mob attacks has left a void in the basic health care system which would take years to rebuild. Therefore, to control the EVD outbreak, the principles of primary health care must be applied. Village health workers should be considered for a potential role in the control of EVD in the current outbreak.

Figure 2: A Village health worker showing a member of the community how to take some tablets. Image drawn by Titilola T. Obilade.

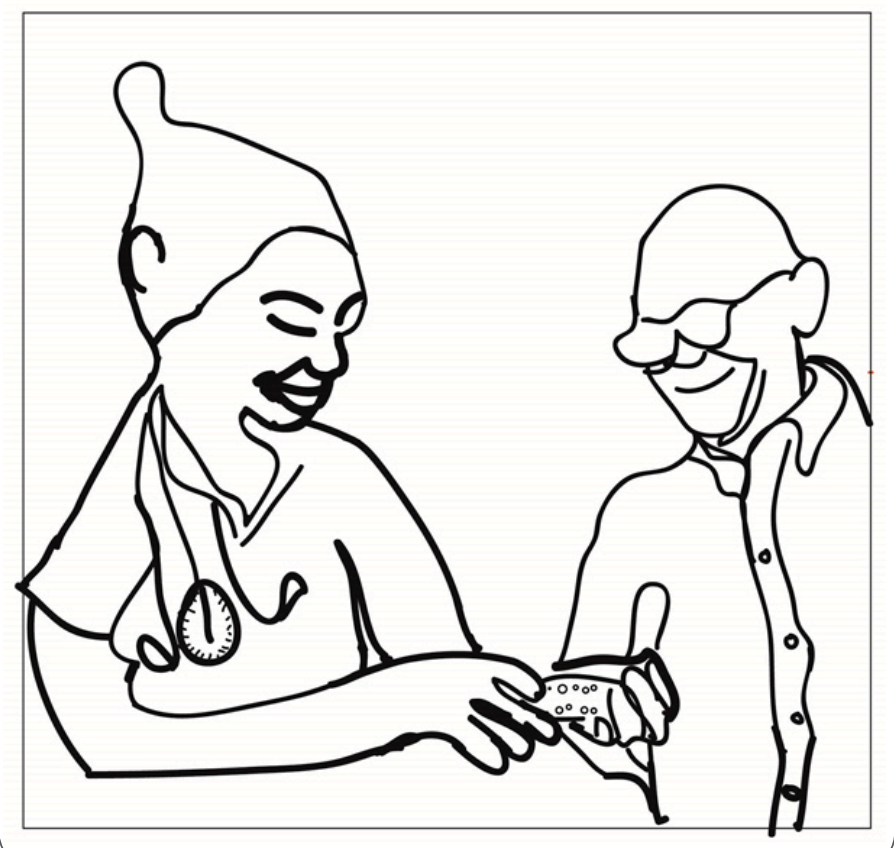

Studies on the Role and Impact of Village Health Workers in Different Countries

There is a relative dearth of studies on VHWs in Liberia, Sierra Leone and Guinea, suggesting a need for research in these areas. The backbone of primary health care is that essential health care can be provided by people living in the community when trained in basic medical care. Research has shown that people are able to put their health care concerns in the hands of members of a community that they trust [43-46].

When 33 prenatal and post-natal women were interviewed in a focus group discussion to determine their level of trust in their health professionals and lay health workers; more than half of the respondents said they trusted the lay health workers [46]. Village health workers in Detroit, USA determined the causes of stress in a community in east side Detroit by conducting in depth interviews and developing interventions to reduce the stress [47].

Women in a community in North Carolina did not want to have a breast cancer screening because they were not comfortable with taking off their clothes before the breast examination and they did not trust the health personnel. However, with the introduction of the lay health advisors that were about the same age as these women, they were encouraged to go for the breast cancer screening $[48,49]$.

In a rural community in India, through the efforts of village health workers, prenatal care increased from $1 \%$ to almost 99\% [50]. Similarly, home-based neonatal care by village health workers in another rural community in India reduced the infant mortality rate by fifty percent [51]. The village health workers had six months of training in the management of the newborn, management of sepsis, history taking, record keeping and management of pneumonia in the new born.

In Zimbabwe, village health workers are being used in the fight against HIVIAIDS to reach the remote areas [52]. After the introduction of community health workers to two underserved districts in Sierra Leone, there was a drop in traditional treatments for diarrhea and there was an increase in appropriate treatment for pneumonia [53]. Vi- 
llage health workers have been employed in the control of EVD outbreak in Uganda [54]. In South Africa, VHWs were trained on how to make sugar salt solutions and they were able to successfully teach mothers to prepare them [55]. In Gambia, a longitudinal study on the impact of introduction of village health workers showed that the infant and child mortality rate had reduced [56]. Villages that had contact with village health workers had knowledge of health promoting and disease preventing practices like oral rehydration therapy, vaccination, use of insecticide treated bed nets, improved sanitation and half of their deliveries were by VHWs.

The Gambian study also showed that when the support for the primary health care was removed, the infant and child mortality rates increased.

\section{Considering Potential Roles for Village Health Workers in the Current Outbreak}

Curative care is not sufficient to control EVD because people in the affected regions are less likely to access the health facilities out of fear of stigmatization and out of fear of dying and not being buried in a culturally acceptable way if they die [57]. Essential health care can be provided by VHWs through contact tracing, monitoring of contacts, health education and counselling.

Further, several people do not have geographic access to health and some do not have the financial access to health. In addition, health care professionals may not agree to work in certain areas. Those who reside in riverine areas may not have a geographic access to a hospital but have access to a village health worker. In addition, there are those who simply do not trust the health care system and will not visit the hospital for a preventive measure. Village health workers are not able to work alone without the assistance of organizations and members of the community but are able to reach remote, rural communities lacking in basic amenities like water and electricity.
In the current EVD outbreak, VHWs have a potential role to play. The governments of the three most affected countries should collaborate with countries that have employed the use of VHWs during EVD outbreaks. Village health workers should be selected from the community that they live in. This gives a sense of ownership and reduces attrition rates. Village health workers should also be motivated because lack of motivation can also cause attrition [58]. They should be the first level of contact with the national health system.

The people in the severely affected nations are suspicious of health care workers coming into their communities and this has led to some health workers being killed. If the VHW was selected by the community, lives and works in the community, it would reduce the antagonism that health care workers face. Primary health care involves community ownership as outlined in the 1978 Alma Ata Declaration.

It (Primary health care) forms an integral part both of the country's health system, of which it is the central function and main focus, and of the overall social and economic development of the community. It is the first level of contact of individuals, the family, and community with the national health system bringing health care as close as possible to where people live and work, and constitutes the first elements of a continuing health care process... (Primary health care) requires and promotes maximum community and individual self-reliance and participation in the planning, organization, operation and control of primary health care, making fullest use of local, national and other available resources; and to this end develops through appropriate education the ability of communities to participate.

Declaration of Alma-Ata International Conference on Primary Health Care, Alma-Ata, USSR, 6-12 September 1978. 
Since village health workers are chosen from the community they live and work in, they are less likely to be fatally antagonised. They would have other sources of income but will also be remunerated for their health services. After selecting those that are willing to become VHWs, they should be sent for training in preventive and clinical health care especially in infectious diseases. They should be taught how to protect themselves against infection. They can take temperatures of community members at temperature stations. History taking from suspected contacts and contact tracing can be done by VHWs. They should also attend refresher courses every few months. When the contact being traced is not in the purview of their village, they would inform the VHW of the village the contact lives in as a follow-up.

In Zimbabwe, village health workers are given bicycles to reach remote areas [51]. They can be given motor cycles and mobile phones to increase accessibility. When patients have been discharged after surviving EVD, the VHW can organize health education sessions for members of the community. They should be remunerated for sustainability.

\section{The Way Forward}

The current EVD outbreak is the longest outbreak in the history of the disease. The countries affected have not faced EVD before and plans must be made for long term management. If the material resources are available and the human resources are not, then the desired control cannot be achieved. When people feel a sense of ownership in their own health, they take better actions. The concept of the village health worker is not new. However, to reduce antagonism towards health care workers and increase a sense of ownership, the community needs to select individuals that would be trained as VHWs in the control of EVD and they can become health educators to their communities. They would be taught contact tracing, health education, infection control protocols, record management and counselling.
Survivors are a good resource for village health workers because they can share their stories and can also become village health workers. There would be different set of skills for different sets of village health workers. Communication devices like mobile phones and radios must be provided. Bicycles and motor cycles must also be provided. In order to reduce burn out of VHW in such intense periods, they could work for a few months and take respite periods while another VHW takes over. The training should be refreshed on a continual basis through refresher courses.

\section{Conclusion}

This paper has attempted to show the potential of incorporating village health workers in the current EVD crisis. First, the paper gave an overview of the EVD and the clinical manifestations of the disease from epidemiologic studies conducted in current and previous outbreaks. It pointed to the loss of infected persons especially health care workers and the subsequent further reduction in human resources. Secondly, it traced the historical path to village health worker in different countries in the context of primary health care to the Alma Ata Declaration in 1978 when the world leaders formally determined that everyone should have equitable access to health. In addition, this paper examined the impact of village health workers in different parts of the world.

Finally, it proposed ways that village health workers can be applied in the current outbreak. In line with the principle of Primary Health Care, the community should select those they want to become their VHW. Village health workers can be used in contact tracing, monitoring temperatures, health education, counselling and as the first contact in the health system. They would also be taught ways to protect themselves. People from outside the community are more likely to be met with antagonism unlike when members of the 
community that are VHWs do similar tasks. They should be provided with bicycles, motor bikes and mobile handsets to gain access to remote areas and to keep them motivated. The governments of the three most affected countries should collaborate with other countries that have employed the use of VHWs in EVD outbreaks. The use of VHWs will buffer the dearth from the loss of health workers, reduce the hostilities that health workers are sometimes met with and reduce the risks of being attacked by angry communities. It would also give a sense of ownership and be an additional source of income.

\section{Acknowledgments}

The author would also like to acknowledge Virginia Polytechnic Institute and State University's Open Access Subvention Fund (OASF).

\section{Author Contributions}

TTO conceived the title and wrote the entire manuscript.

\section{Conflicts of Interest}

None

\section{References}

1. WHO. Ebola response team Ebola Virus Disease in West Africa - The First 9 Months of the Epidemic and Forward Projections. [cited 2015 February, 27]. Available online: http://www.nejm. org/doi/pdf/10.1056/NEJMoa1411100

2. Briand, S, Bertherat, E, Cox, $P$, et al. The international Ebola emergency. N Engl J Med. 371 (13)1180-1183. September 25, 2014. doi: 10.1056/NEJMp1409858

3. Saéz AM, Weiss $S$, Nowak $K$, Lapeyre $V$, Zimmermann F, Düx $A$, et al. Investigating the zoonotic origin of the West African Ebola epidemic2014 2014-12-29 00:00:00. Embo Molecular medicine. [cited 2015 February, 27]. Available on line: http://embomolmed.embopress.org/content/embomm/ early/2014/12/29/emmm.201404792.full.pdf

4. Paessler S, Walker DH. Pathogenesis of the viral hemorrhagic fevers. Annual review of pathology. 2013; 8: 411-440.

5. Negredo A, Palacios G, Vázquez-Morón S, González F, Dopazo $H$, Molero $F$, et al. Discovery of an ebolavirus-like filovirus in europe. PLoS pathogens. 2011; 7(10): e1002304.

6. Barrette RW, Metwally SA, Rowland JM, Xu L, Zaki SR, Nichol ST, Rollin PE, Towner JS, Shieh W-J, Batten B et al.: Discovery of Swine as a Host for the Reston ebolavirus. Science 2009, 325: 204-206.

7. Feldmann H. Ebola-A Growing Threat? N Engl J Med 2014; 371: 1375-1378, October 9, 2014 DOI: 10.1056/NEJMp1405314. [cited 2015 February, 27]. Available online: http://www.nejm. org/doi/full/10.1056/NEJMp1405314

8. Siegert R, Shu HL, Slenczka W, Peters D, Muller G. [On the etiology of an unknown human infection originating from monkeys] Dtsch Med Wochenschr 1967; 92: 2341-2343.

9. Leroy EM, Kumulungui $B$, Pourrut $X$, Rouquet $P$, Hassanin $A$, Yaba P, De' licat A, Paweska JT, Gonzalez J-P, Swanepoel R: Fruit bats as reservoirs of Ebola virus. Nature 2005, 438: 575-576.

10. Swanepoel R, Leman PA, Burt FJ, et al. Experimental inoculation of plants and animals with Ebola virus. Emerg Infect Dis 1996; 2: 321-325.

11. Baize S, Pannetier D, Oestereich L, Rieger T, Koivogui $L$, Magassouba NF, et al. Emergence of Zaire Ebola Virus Disease in Guinea. N Engl J Med. 2014; 371(15): 1418-1425.

12. Shuaib, F.; Gunnala, R.; Musa, E.O.; Mahoney, F.J.; Oguntimehin, O.; Nguku, P.M.; Nyanti, S.B.; Knight, N.; Gwarzo, N.S.; Idigbe, O.; et al. Ebola Virus Disease Outbreak-Nigeria, July-September 2014. MMWR Morb. Mortal. Wkly. Rep. 2014, 63, 867-872.

13. Mirkovic, K.; Thwing, J.; Diack, P.A. Importation and containment of Ebola virus disease-Senegal, August-September 2014. MMWR Morb. Mortal. Wkly. Rep. 2014, 63, 873-874.

14. WHO. Global Alert and Response (GAR) Successful Ebola responses in Nigeria, Senegal and Mali. [cited 2015 February, 27]. Available from: http://www.who.int/csr/disease/ebola/oneyear-report/nigeria/en/ 
15. Peters CJ, Jahrling PB, Khan AS. Patients infected with highhazard viruses: scientific basis for infection control, Arch Virol 1996; 11(suppl): 141-168.

16. Roels, T, Bloom, A, Buffington, J, et al 1999. Ebola hemorrhagic fever, Kikwit, Democratic Republic of the Congo, 1995: risk factors for patients without a reported exposure. J Infect Dis, 179, S92-S97.

17. Martines RB, Ng DL, Greer PW, Rollin PE, Zaki SR. Tissue and cellular tropism, pathology and pathogenesis of Ebola and Marburg viruses. J Pathol. 2015; 235(2): 153-174.

18. Biosafety in Microbiological and Biomedical Laboratories 5th Edition pp. 1-8, pp. 24-26; CDC, USDHHS, NIH. [cited 2014 December, 23]. Available online: http://www.cdc.gov/biosafety/ publications/bmbl5/BMBL.pdf

19. Baize S. Ebola virus in West Africa: new conquered territories and new risks-or how I learned to stop worrying and (not) love Ebola virus. Current opinion in virology. 2015; 10: 70-76.

20. Report of a WHO/International Study Team. Ebola Haemorrhagic Fever in Sudan, 1976. Bull. World Health Organ. 1978, 56, 247270.

21. Report of an International Commission. Ebola Haemorrhagic Fever in Zaire, 1976. Bull. World Health Organ. 1978, 56, 271 293.

22. Feldmann H. Ebola-A Growing Threat? N Engl J Med 2014; 371: 1375-1378, October 9, 2014 DOI: 10.1056/NEJMp1405314. Available on line: http://www.nejm.org/doi/full/10.1056/ NEJMp1405314 (accessed on 23 October, 2014).

23. Kortepeter MG, Bausch DG, Bray M. Basic clinical and laboratory features of filoviral hemorrhagic fever. Journal of Infectious Diseases. 2011; 204(suppl 3): S810-S6.

24. Bwaka MA, Bonnet MJ, Calain $P$, et al. Ebola hemorrhagic fever in Kikwit, Democratic Republic of the Congo: clinical observations in 103 patients. J Infect Dis 1999; 179(Suppl 1): S1-7.

25. Ndambi R, Akamituna P, Bonnet MJ, Tukadila AM, MuyembeTamfum JJ, Colebunders R. Epidemiologic and clinical aspects of the Ebola virus epidemic in Mosango, Democratic Republic of the Congo, 1995. J Infect Dis 1999; 179(Suppl 1): S8-10.

26. WHO. Sierra Leone: for Ebola survivors the pain goes on. Geneva: WHO, 2014. [cited 2015 February 28]. Available from: http://www.who.int/features/2014/post-ebola-syndrome/en/

27. Schieffelin JS, Shaffer JG, Goba A, Gbakie M, Gire SK, Colubri $A$, et al. Clinical IIIness and Outcomes in Patients with Ebola in Sierra Leone. New England Journal of Medicine. 2014; 371(22): 2092-2100.

28. UNDP Human Development Reports. Table 1: Human Development Index and Its Components [cited 2015 February, 5]. Available from: http://hdr.undp.org/en/content/table-1human-development-index-and-its-components

29. Chan M. Ebola virus disease in West Africa-no early end to the outbreak. New England Journal of Medicine. 2014.
30. Green A. Remembering health workers who died from Ebola in 2014. The Lancet. 384(9961): 2201-2206.

31. WHO. Report by the Director-General to the Special Session of the Executive Board on Ebola. [cited February 26, 2015]. Available from: http://www.who.int/dg/speeches/2015/executive-boardebola/en/

32. PSI. PSI names the 325 health workers killed by Ebola, victims of corporate interests and social injustice. [cited 2015 February, 26] Available from: http://www.world-psi.org/en/psi-names-325health-workers-killed-ebola-victims-corporate-interests-andsocial-injustice-0

33. BBC. Ebola Outbreak: Guinea health team killed. 18 Sept 2014. [cited 2015 February, 26]. Available from: http://www.bbc.com/ news/world-africa-29256443

34. Yahoo. Mob kills men in Guinea suspected of spreading Ebola. [cited 2015 February, 26]. Available from: http://news. yahoo.com/mob-kills-men-guinea-suspected-spreadingebola-155056184.html

35. Sidel VW. The barefoot doctors of the People's Republic of China. The New England journal of medicine. 1972; 286(24): 1292-3000

36. Kauffman KS, Myers DH. The changing role of village health volunteers in northeast Thailand: an ethnographic field study. International journal of nursing studies. 1997; 34(4): 249-255.

37. WHO. Health by the people. 1975. [cited 2015 February, 26]. Available from: http://apps.who.int/iris/ bitstream/10665/40514/1/9241560428_eng.pdf

38. Declaration of Alma-Ata International Conference on Primary Health Care, Alma-Ata, USSR, 6-12September 1978. [cited 2015 February 2015]. Available from: http://www.who.int/ publications/almaata_declaration_en.pdf?ua=1

39. Chagula WK Tarimo E. Meeting Basic Health needs in Tanzania. In (WHO) Health by the people. 1975.pp. 145-168. [cited 2015 February, 26]. Available from: http://apps.who.int/iris/ bitstream/10665/40514/1/9241560428_eng.pdf

40. Fournier G Djermakoye IA. Village health teams in Niger (Maradi department). In (WHO) Health by the people. 1975.pp.128-144. [cited 2015 February, 26]. Available from: http://apps.who.int/ iris/bitstream/10665/40514/1/9241560428_eng.pdf

41. Sofoluwe GO, Schram R, Ogunmekan DA. (Eds.). Principles and practice of public health in Africa, Volume 1. Nigeria: University Press.1996.

42. WHO. Community health workers: What do we know about them? The state of the evidence on programmes, activities, costs and impact on health outcomes of using community health workers. 2007. [cited 2015 February 2015]. Available from: http://www.who.int/hrh/documents/community_health_ workers.pdf

43. Gilson L. Trust and the development of health care as a social institution. Social science \& medicine. 2003; 56(7): 1453-1468. 
44. Whetten K, Leserman J, Whetten R, Ostermann J, Thielman N, Swartz $\mathrm{M}$, et al. Exploring lack of trust in care providers and the government as a barrier to health service use. American Journal of Public Health. 2006; 96(4): 716 -720.

45. Mohseni M, Lindstrom M. Social capital, trust in the health-care system and self-rated health: the role of access to health care in a population-based study. Social science \& medicine. 2007; 64(7): 1373-1383.

46. Sheppard VB, Zambrana RE, O'Malley AS. Providing health care to low-income women: a matter of trust. Family Practice. 2004; 21(5): 484-491.

47. Schulz AJ, Parker EA, Israel BA, Allen A, Decarlo M, Lockett M. Addressing social determinants of health through communitybased participatory research: the East Side Village Health Worker Partnership. Health Education \& Behavior. 2002; 29(3): 326-341.

48. Earp JAL, Viadro Cl, Vincus AA, Altpeter M, Flax V, Mayne L, et al. Lay health advisors: a strategy for getting the word out about breast cancer. Health Education \& Behavior. 1997; 24(4): 432-451.

49. Eng E. The Save our Sisters Project. A social network strategy for reaching rural Black women. Cancer. 1993; 72(S3): 1071-1077.

50. Mesce D. Lessons learned from a community based health care project. [cited 2015 February, 26]. Available from: http://www. prb.org/Publications/Articles/2007/LessonsLearnedCommunityBasedProject.aspx

51. Brown B. Home-based neonatal care by village health workers in rural India reduces deaths from bacterial infection. International Family Planning Perspectives. 2000; 26(2): 92-93.

52. UNICEF. In Zimbabwe, village health workers play an essential role in the primary healthcare system and the fight against HIV/ AIDS. [cited February 24 2015]. Available from: http://www. unicef.org/infobycountry/zimbabwe_66508.html

53. Yansaneh Al, Moulton LH, George AS, Rao SR, Kennedy N, Bangura $\mathrm{P}$, et al. Influence of community health volunteers on care seeking and treatment coverage for common childhood illnesses in the context of free health care in rural Sierra Leone. Tropical Medicine \& International Health. 2014; 19(12): 14661476.

54. Mbonye AK, Wamala JF, Nanyunja M, Opio A, Aceng JR, Makumbi I. Ebola viral hemorrhagic disease outbreak in west Africa-lessons from Uganda. African health sciences. 2014; 14(3): 495-501.

55. Yach D, Hoogendoorn L, Von Schirnding Y. Village health workers are able to teach mothers how to safely prepare sugar/ salt solutions. Paediatric and perinatal epidemiology. 1987; 1(2): 153-161.
56. Hill A, MacLeod W, Joof $D$, et al. Decline of mortality in children in rural Gambia: the influence of village-level primary health care. Trop Med Int Health 2000; 5: 107-118

57. Obilade TT. Ebolavirus disease stigmatization: The role of societal attributes. International Archives of Medicine. 2015; 8(14) 1-19. doi: 3823/1613. Available from: http://imed.pub/ojs/index.php/ iam/article/view/1007/674

58. Brunie A, Wamala-Mucheri P, Otterness C, Akol A, Chen M, Bufumbo L, et al. Keeping community health workers in Uganda motivated: key challenges, facilitators, and preferred program inputs. Global Health: Science and Practice. 2014;2(1):103-116.

\section{Comment on this article:}

\section{(f) $[$ in $8+\boldsymbol{S}$ P}

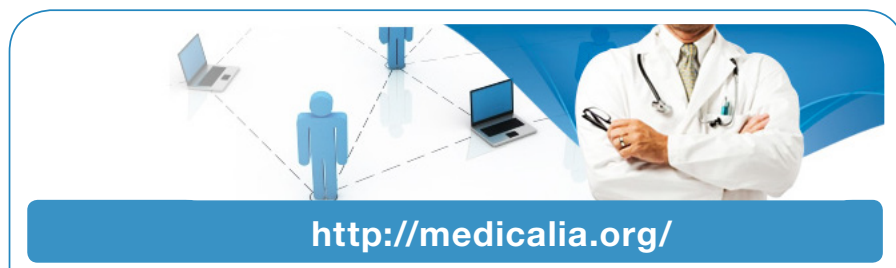

Where Doctors exchange clinical experiences, review their cases and share clinical knowledge. You can also access lots of medical publications for free. Join Now!

\section{Publish with iMedPub}

\section{http://www.imed.pub}

International Archives of Medicine is an open access journal publishing articles encompassing all aspects of medical science and clinical practice. IAM is considered a megajournal with independent sections on all areas of medicine. IAM is a really international journal with authors and board members from all around the world. The journal is widely indexed and classified Q1 in category Medicine. 